\title{
F.T. Tomoioagă
}

\section{THE VISION OF DIVINE LIGHT IN SAINT GREGORY PALAMAS'S THEOLOGY}

\begin{abstract}
The Hesychast debates of the 14th century between the representatives of the Western and Eastern tradition over the issue of the light seen in the experience of prayer are still relevant nowadays. Gregory Palamas - who was the central figure of these debates - was rediscovered in the 20th century by Orthodox Theology and is still in the process of reception in Western theology. The present study represents a synthesis of Saint Gregory Palamas's teaching on the vision of Divine Light as it was articulated in the debate with his adversaries. Directly linked to this topic are other adjacent issues, namely the Transfiguration of Christ, the intellectual and the mystical knowledge, the nature of the divine energies, the purpose of the Christian life, and so on. The entire study in couched in the frame of a personal reflection over the type of spirituality fit for contemporary man - a contemplative one of a mystical type or a much more practical one, based on social virtues?
\end{abstract}

\section{REDISCOVERING PALAMAS}

A few months ago, a monk was invited in Romania to deliver a lecture about the monastic spirituality of Mount Athos, in the frame of a cultural festival named Philokalia, which celebrated sacred art and beauty. At a certain point, being himself a Hesychast, he affirmed that one of the strongest temptations of the Hesychast is to abandon his seclusion, his isolation and to return into the world. The temptation takes the form of questions: Why should one pursue a solitary deification through a life of

Florin Toader Tomoioagă, assistant lecturer at the Faculty of Orthodox Theology "Episcop Dr. Vasile Coman", University of Oradea, Romania. E-mail address: tomoioagaf@teoradea.ro 
ascetic renunciation, meditation and prayer and not serve one's brothers, who are Christ's images, with a practical love, offering them support in their ordinary needs or spiritual struggles? Can the deification, which is the goal of Eastern monasticism, be attained without the contact with our fellow human beings? From an honest biblical point of view, should one follow Symeon Stylites' ideal of trying to attain perfection or Mother Theresa's purposes of bringing comfort among the lepers and the sick people of India? Or is it possible to combine the two divergent perspectives in one unique ideal?

The question that tempts the Hesychast of our story is a source of inner struggle and tension, a subtle battle in the realm of personal conscience. This sincere confession makes me think that he is not a unique case. And this is precisely what we frequently tend to forget when we discuss the tensions that marked the development of Christian monasticism, or, as it is with this topic, shaped Eastern monastic life. These tensions are not part of a history of ideas, of the polemics of the past, but they return, in one form or another, in every responsible and faithful Christian conscience, be it a layperson or a churchman, and determine choices and ways of devotion.

For the past six hundred years, at least in Eastern Christianity, with regard to the above questions, the choice was made in favour of the hesychast contemplative life, but not without difficulties and disruptions. During this period, the personality and teaching of Saint Gregory Palamas, which were at the core of the Hesychast controversy, were almost totally forgotten. They were rediscovered only in the mid-20 th century, through the scholarly work of pioneers such as father Dumitru Stăniloae, John Meyendorff, Christou Panayiotis, and others. The critical editions of his work are not yet completed, and Professor Vasilis Psevtokas, a former disciple and collaborator of Christou, prepares the sixth and last volume of the Palamas work. This volume contains the 63 Homilies delivered by Saint Gregory while he was archbishop of Thessaloniki and is elaborated on the bases of microfilmed manuscripts housed in Thessaloniki's Institute of Patristic Studies. The Greek publishing house that published the first five volumes, Oikos Kyromanos, will also publish the 650-page volume in 2015.

But, even in the absence of a critical edition, the Palamas teaching, especially the former controversial distinction between ousia and divine energies in God, is generally admitted in Orthodox theology at present. Moreover, as Bishop Kallistos Ware mentions, the Hesychast Synods from 1341, 1347, 1351 and 1368 have practically the same importance for the Orthodox conscience as the ecumenical synods. Hesychast spirituality inspired new forms of personal and communitarian ascetic life, as is, for example, the movement from Essex, represented by the elder Sofronios 
Sacharov. It surely reshaped the theological discourse of Dogmatic Theology in the $20^{\text {th }}$ century. I mention only a few representatives, namely Nikos Matsoukas in Greece; father Justin Popovich in Serbia; Vladimir Lossky in the Russian Diaspora, and, of course, father Dumitru Stăniloae in Romania.

\section{THE RECEPTION OF SAINT GREGORY PALAMAS'S THEOLOGY IN THE WEST}

In the West, the reception of Saint Gregory Palamas's theology, as it is known, was rather a negative one. His doctrine of divine light was rejected, because it postulated the possibility of seeing God with corporeal eyes (Lossky 1975:62). According to Vladimir Lossky, this attitude is determined by

a certain aftertaste of Manicheism, almost imperceptible, which still remains in our (Western) piety and which at times makes us despise the flesh a little too much, not because of sin, but by virtue of its material nature (Lossky 1975:63).

When, in 1865, the Roman-Catholic priest Jacquest-Paul Migne published the work of Palamas, volumes 150-151 of the series Patrologia Graeca, he warned the readers that, although he initially wanted to exclude them from the volumes, he decided to include them, because "the palamite heresy, banished away many centuries ago by its own absurdity, belongs now to history and it is not anymore a fear that its exposure will be a threat for somebody" (Palamas 2009:16). Martin Jugie, who took the time to read Palamas, was bemused by the doctrine of "uncreated light" and more generally by the notion of "divine energies", seeing in such formulations a dangerous impairment of the Nicene doctrine of God (Palamas 1983:XI).

From his point of view, Palamas invented a theology that is rejected by the most elementary Christian philosophy and theology. The origin of the palamite doctrine must be viewed in the false mysticism that emerged in the Byzantine Church, at a time when it was severing the last connections that linked it with the Church of Rome (Palamas 2009:25).

This situation began to change. In a preface to the English edition of the Triads, Yaroslav Pelikan writes:

The rehabilitation of Gregory Palamas in the Western Church during the twentieth century is a remarkable event in the history of scholarship, and the inclusion of a volume of Palamas in a series bearing the title "Classics of Western Spirituality" is itself a remarkable symbol of that rehabilitation (Palamas 1983:XI). 
And he continues:

\begin{abstract}
But now, apparently, he is becoming a saint to increasing parts of the Western Church as well-an uncanonized saint, to be sure, but one who deserves attention as something more than a museum piece from Mount Athos. The successor to The Catholic Encyclopedia as a standard work of general reference, the New Catholic Encyclopedia, comments, in an article by the Dominican scholar Daniel Honorius Hunter: "Palamite doctrine on the divine nature of the light of Mt. Thabor and the visible presence of uncreated grace in the pure of heart has been an obstacle for Western theologians in accepting Palamas as a teacher of orthodoxy. On the other hand, Palamas's insistence that the whole man is engraced, body and soul, and the stress that he placed on the role of the body in prayer has been adopted in the West by recent theologian" (Palamas 1983:XI-XII).
\end{abstract}

\title{
3. THE POLEMICS SURROUNDING THE HESYCHAST METHOD OF PRAYER
}

Like the majority of Church Fathers, Saint Gregory began to write under the pressure of circumstances, in this case, in defence of the Hesychast method of prayer. Barlaam the Calabrian, a Western monk of Greek origins, started the controversy when he attacked the method and the teachings involved in it, which culminated with the possibility of seeing the divine light. Barlaam wrote his first treatises after a period of apprenticeship under some uneducated monks. They assert - according to his account - that, during the ecstatic experience of prayer, they cleanse their soul from the demons that adhere to it through the passions, and that, at the end of this process, they see the divine nature. Barlaam accused the Hesychastic monks of Messelianism, of "claiming a material vision of God" (Lossky 1983:154).

We cannot exclude the fact that, among the monks who used the Hesychast method of prayer, there were some who professed teachings close to Messalianism or more precisely, to Bogomilism. For this reason, Saint Gregory reproaches Barlaam for gathering information from the least experienced ascetics and not from those with an authentic knowledge and experience. Therefore, without a correct knowledge of the situation, Barlaam blamed the whole Hesychast practice as a false mysticism.

The main issue at stake was the problem of communion with God and of the way in which one realises this. Other themes emerged: Is such a communion possible in this life? What does this communion consist of? What is the role of knowledge in establishing this communion? What kind 
of knowledge is involved in this? How does the human mind participate in this process? Is the human body part of this experience? Is the deification a gift of the future or can it be realized partially in this life? What do the theophanic manifestations of the divine light in the Scripture represent? What is the nature of this Light? Is God accessible or inaccessible, visible or invisible?

In the context of this debate, Saint Gregory assumed the mission to prove that a real communion with God was possible through sanctification and that the vision of God granted by prayer was a sign of this spiritual communion. From the outset, Palamas refuses to identify the vision of God with the vision of the nature of God. The nature of God was invisible, but it was the divine light or energy that was accessible to the human spirit. At this point, the modern commentators of Saint Gregory trace an evolution in his thinking regarding the former patristic tradition. It is the distinction made between the transcendent, unapproachable and unknowable divine ousia, and the divine energies that belong to it and that are communicated to men through the Trinitarian Persons. But is this feature of Palamas's theology such a revolutionary one?

Briefly, it can be stated that it is a step forward, but not beyond the former tradition. Saint Gregory frequently quotes his predecessors: Macarius the Great, Basil the Great, Gregory the Theologian, John Chrysostom, Dyonisius Areopagite, Symeon Metaphrastes, John Climacus, Maximus the Confessor, John Damascene, Symeon the New Theologian, and others. From his perspective, the teaching about the divine energies is synonymous with the teaching about the divine grace which manifested itself in the vision of the biblical prophets and more openly in the life and person of Jesus Christ.

On the other hand, Barlaam insisted on the apophatic character of divinity. In his appeal to the Fathers, he uses a different interpretation. Thus, the apophatic theology of Saint Dionysius the Areopagite is simply agnosticism. According to Barlaam, the negations used by the author of the treaties On the Divine Names and Mystical Theology are proof of the utterly unknowable character of God. We cannot know God in this life directly, and if $\mathrm{He}$ communicates with us, He does so through the symbols of the visible world. The rejection of the Hesychast spirituality and theology is based on his appeal to natural theology as the only source of knowing God.

At this point, Palamas notices that, along with the denial of the experience of God as Revelation and personal encounter, Barlaam dismisses even the revealed character of the Holy Scripture. He is accused of atheism, maybe due to the fact that natural theology, based exclusively on human reason, can always find its sources of negation in the same 
human reason. In his interpretation of Dionysius the Areopagite, Saint Gregory is overwhelmed with wonder: Is it not obvious to everybody that Dionysius's apophaticism is the result of a union with God? Dionysius expresses the inability of the human mind to describe the depths of this union with the divine. However, what is ineffable at the level of language is accessible at the level of experience.

Saint Gregory professes a double gnostic methodology: natural knowledge enables man to approach the natural order, and spiritual knowledge en toables man access the spiritual reality. The former is inferior to the latter. Understanding oneself, almost following Socrates, and knowing God is more important than having scientific understanding (Palamas, Capita 150.29). The connection between the Socratic selfknowledge and the knowledge of God is a permanent feature in Greek theology, and, closer to our era, Saint Nectarios of Aegina entitled his treatise of Ethics Know Thyself - Gnothi seauton - or About Virtues.

\section{THE ETHICAL AND MYSTICAL ASPECTS OF THE DEBATE}

Both the representatives of the two clashing civilisations and Churches agree on the unconditional nature of a practical life of sainthood in order to attain redemption. While for Barlaam this includes profane knowledge, often situated above virtues, for Palamas it presupposes a mystical knowledge, i.e. a strong and very sensible relationship with God, expressed through ceaseless prayer that culminates in the sight of the Divine Light. This light is not something that interferes between man and God; it is the very presence of God, His blessing and grace. The virtues are preparing man for the union with God, but this is granted as a gift only through mental prayer. The vision of the Divine Light is, therefore, the work of the Holy Spirit, granted to the human soul, which is prepared for such an experience by the ceaseless prayer that brings the purification of the heart (Dumitrașcu 2010:179).

Deification is the fulfilment of Christian life, which has at its foundation the achievement of virtues, the practice of commandments. Is deification an obligatory condition for salvation? Saint Gregory wrote a Christian revision of the ten commandments of Decalogue, in which the Hesychast ideals (deification, vision of light, mental prayer, and prayer of the heart) vanished. All that is left is the fulfilment of the commandments. This makes social life bearable and, ultimately the promise of the inheritance of the eternal goods. Salvation is thus possible without deification and it seems that, unlike Saint Symeon the New Theologian, sainthood is possible 
without deification and personal salvation can be attained without reaching the supernatural peaks of askesis. This short treatise of Palamas destroys an Orthodox theological cliché: the one that opposes Imitatio Christi to Life in Christ, Thomas à Kempis to Nicolas Cabasilas, exteriority and interiority in following Christ. Finally, the spirituality expressed by the Calabrian theologian suggests, from this point of view, the following of Christ in an accessible and less in a mystical manner. It is not surprising that nowadays Western Christianity proposes some virtues that have significance for a man living in society, whereas Eastern Christianity fascinates with its mysticism, but is still reluctant to approach social problems.

\section{THE NATURE AND VISION OF THE DIVINE LIGHT}

Barlaam's attitude shifted with regard to the light seen by the prayerful Hesychast. At first, he considered it a demonic delusion, but when Saint Gregory wrote convincingly against him, he described it as a natural light, a created symbol acting like an interface between God and men. In his opinion, it is simply the light of natural knowledge, a reflection of the mind upon itself, the inner illumination of a smart brain that possesses scientific and philosophic understanding. From his point of view, Palamas's insistence upon the uncreated nature of the divine light tears down the simplicity of God, attracting upon him the accusation of ditheism.

In fact, St. Gregory Palamas's adversaries professed a kind of intellectualism of Eastern origins:
overcome within theology, the old Hellenism reappears in the writings of the humanists who, formed by their studies of philosophy, wish to see the Cappadocians through the eyes of Plato, Dionysius through the eyes of Proclus, Maximus and John Damascene through the eyes of Aristotle (Lossky 1983:156).

For them, the divine light and the union with God in this life were mere metaphors.

To defend himself, Palamas resorted, on many occasions, to Christology. Unavoidable, the polemic highlighted the famous biblical episode of Christ's Transfiguration on Mountain Thabor. Saint Gregory resumes the patristic tradition when he maintains that the Apostles perceived the divine light in the presence of the transfigured Christ. The Lord of glory does not change in this instance, but the Apostle's eyes change for a moment. They can contemplate the divine light, streaming from His divinity through the veil of His assumed humanity. As God Himself, this light is both uncreated and eternal, communicating to us not a substitute of God, but God Himself. 
In the Triads in defence of the Holy Hesychasts, in reply to Barlaam's theory, Saint Gregory affirms:

Thus if the light of Thabor is a symbol, it is either a natural or a nonnatural one. If the latter, then it either has its own existence or is just a phantom without subsistence. But if it is merely an insubstantial phantom, then Christ never really was, is or will be such as $\mathrm{He}$ appeared on Thabor. Yet Denys the Areopagite, Gregory the Theologian and all the others who await His coming from heaven with glory affirm clearly that Christ will be for all eternity as He then appeared, as we showed above. This light, then, is not just a phantom without subsistence (Palamas, Hyper tōn hierōs hesychazontōn 3.1.14).

The Transfiguration is not merely about the Lord, but about the Apostles's eyes, which suffered a transmutation. They were thus able to see the unseen, to comprehend the incomprehensible. At this point, Saint Gregory quotes a patristic authority:

Hear John Damascene, who is wise in divine things: "Christ is transfigured, not by putting on some quality $\mathrm{He}$ did not possess previously, nor by changing into something He never was before, but by revealing to His disciples what He truly was, in opening their eyes and in giving sight to those who were blind. For while remaining identical to what $\mathrm{He}$ had been before, $\mathrm{He}$ appeared to the disciples in His splendour; $\mathrm{He}$ is indeed the true light, the radiance of glory" (Palamas, Hyper tōn hierōs hesychazontōn 3.1.15).

How do the Apostles view the Thaboric light? Of course, this does not happen naturally and it is not an extracorporeal vision. To reconcile the oppositions, Saint Gregory affirms the antinomy: God Himself makes the Apostles able to see His light through their spirit (nous), not outside the body, but in the body:

The light, then, became accessible to their eyes, but to eyes which saw in a way superior to that of natural sight, and had acquired the spiritual power of the spiritual light. This mysterious light, inaccessible, immaterial, uncreated, deifying, eternal, this radiance of the Divine Nature, this glory of the divinity, this beauty of the heavenly kingdom, is at once accessible to sense perception and yet transcends it (Palamas, Hyper tōn hierōs hesychazontōn 3.1.23).

A modern commentator of Palamas emphasises a similar perspective:

The vision of the uncreated glory of God did not happen simply to the natural eyes and the natural sensation, because that light was 
not natural ... the Light was the Light of divinity and not something created. However, the disciples saw the glory of Christ even with their eyes, which had previously been transfigured and had been deemed worthy of this vision of God. Therefore we also have the transfiguration of the Disciples on Mt. Thabor and not only that of Christ (Hierotheos 2000:339).

In addition, Palamas develops a theory of Christ's divine glory during His earthly life. The incarnate Logos has the divine glory together with His divine nature. If in John 17:5 He requires it from the Father, He asks it not for His divinity, but for His assumed humanity. This is commonplace in patristic literature. Among others, Saint Cyril of Alexandria wrote extensively on this topic. In his perspective, Christ permanently reveals His glory; He does not hide it. The disbelief and spiritual blindness of His contemporaries renders them unable to perceive the divine shining of Christ's glory.

Saint Gregory explains that, in the case of the Hesychast, this sight is, in fact, a union with the light, and the vision is granted by the Holy Spirit; in the frame of vision-union, the beholder himself becomes a light who sees light with the help of light:

\begin{abstract}
So to return - the contemplation of this light is a union, even though it does not endure with the imperfect. But is the union with this light other than a vision? And since it is brought about by the cessation of intellectual activity, how could it be accomplished if not by the Spirit? For it is in light that the light is seen, and that which sees operates in a similar light, since this faculty has no other way in which to work. Having separated itself from all other beings, it becomes itself all light and is assimilated to what it sees, or rather, it is united to it without mingling, being itself light and seeing light through light. If it sees itself, it sees light; if it beholds the object of its vision, that too is light; and if it looks at the means by which it sees, again it is light. For such is the character of the union, that all is one, so that he who sees can distinguish neither the means nor the object nor its nature, but simply has the awareness of being light and of seeing a light distinct from every creature (Palamas, Hyper tōn hierōs hesychazontōn 2.3.36).
\end{abstract}

Some years later, a letter sent by Saint Gregory to the nun Xeni echoes the above famous passage from the Triads. In a significant fragment, he describes the mind's ascension to God in light. Spiritual ascension begins with the mind's purification of every sinful passion and with the return to itself. After passing beyond all mental and material images and meanings, the mind is transformed through the work of grace, which shines with unspeakable light in the inner man. Using the light as a pathway, the nous 
ascends above everything through the power of the Holy Spirit, gathers a spiritual sense through which the unheard is heard, and sees the unseen and participates with the One who is above everything (Palamas, Pros Xenin monahin 58-59).

I am of the opinion that the quoted passage is a Christian reply to Plato's ascensions of the soul to the Supreme Beauty from the Symposium, the main difference being that, in this instane, the "vehicles" of ascension are not "the imaginative wings of thinking", but the light and the power of the Holy Spirit.

Palamas's theological thinking is very coherent. His Christology corresponds to his anthropology, and both to his mysticism. According to Fr. Fadi Georgi,

\begin{abstract}
Palamas considers the redeeming work of Christ as the foundation of the theology of light. In this theological frame, the fall of Adam is represented as his separation from Beauty and Light and as the alienation from the divine "form" and the original destiny of humanity (Georgi 2010:149).
\end{abstract}

Created in the image of God, man realizes the likeness through union with God. In this way, he gets back the lost beauty of sainthood after the image of God. Thus, the vision of the divine light is a return to the innocent state of man. In paradise, Adam was clothed with a garment of light, which he ultimately lost through the original sin (Papademetriou 1973:46). On Mount Thabor, Christ gives this shining garment to the human being. His transfiguration is a prophecy regarding our eschatological transfiguration. But even in the present age, the true Christian foretastes the future state when "the righteous will shine like the sun in the kingdom of their Father" (Matthew 13:43) (Hierotheos 2000:342-343). The Hesychast method is only activation or rediscovery of the sacrament of Baptism, which bestows on man the deifying light of grace (Meyendorff 1959:118).

In this polemic, one notices a different interpretation by the Church Fathers. We have noted Barlaam's reading of Dionysius. But the same is true of Saint Gregory. In at least three of his treatises, he uses Saint Augustin on a large scale, but without quoting him and reinterpreting him. In a homily on the eikonomical work of Christ, the result is a Byzantine version of the anselmian Cur Deus Homo.

There is also a different reading of Scripture. For Barlaam, many biblical passages about light, the indwelling of the Spirit, and the vision of God are simply beautiful metaphors or things of the future. His nominalism consists in the fact that he refuses to recognize them as realistic descriptions of 
the spiritual life and, more precisely, of the present life. On the contrary, for Saint Gregory and for the Eastern monastic tradition, these words denote mystical realities, which are accessible to the purified person. They describe not only eschatological realities, but also their partial fulfilment and foretasting in the life of a devoted Christian. Such is, for example, the passages from Matthew 5:8: "Blessed are the pure in heart, for they will see God" or from John 14:21, 23:

Whoever has my commands and keeps them is the one who loves me. The one who loves me will be loved by my Father, and I too will love them and show myself to them... Anyone who loves me will obey my teaching. My Father will love them, and we will come to them and make our home with them (Palamas, Hyper tōn hierōs hesychazontōn 1.3.15).

One of the most important passages is, of course, from Luke 17:21: "The kingdom of God is within you".

\section{INSTEAD OF CONCLUSIONS}

I would like to make a few remarks and raise a question. First, the remarks. The palamite controversy about communion, deification, vision of light, apophatic or cathaphatic theology started with the interpretation of Scripture from the perspective of the Fathers. Finally, the ancient mystical tradition supported by Palamas and his followers prevailed over the conceptions of his adversaries, at least in the East. But, despite the fact that the reason was mutual negation between East and West, Palamas often succeeded in avoiding the polarities East-West, for example by using Augustine as a source of inspiration. And now my question: Is it possible that, after so many years during which the teaching of Saint Gregory was another reason for the estrangement between East and West, once translated and rediscovered may offer room for reconciliation? We will see. The solution was proposed many years ago by the distinguished researcher Vladimir Lossky who suggested that a mutual understanding between West and East is possible only if the Eastern tradition were judged not "through the rigid concepts of an academic tradition", but as "fruitful sources of spiritual renewal". Then maybe, the Eastern spirituality will be rediscovered, as it was the case with the Byzantine art, especially the icon, which was appreciated in the West after many years of being disregarded (Lossky 1975:69). 


\section{BIBLIOGRAPHY}

Dumitrașcu, $\mathbf{N}$.

2010. Bucuria iluminării divine la Sfântul Grigorie Palama în câteva note și comentarii ale părintelui Dumitru Stăniloae (The Joy of Inner Enlightenment to Saint Gregory Palamas in a Few Footnotes and Commentaries of Fr. Dumitru Stăniloae). Studia Theologica, vol. II. Craiova: Editura Mitropoliei Craiova:179.

Georgi, F.

2010. The vision of God as a foretaste of eternal life according to Saint Gregory Palamas. In: M. Tamcke (ed.), Gotteserlebnis und Gotteslehre: Christliche und islamische Mystik im Orient. Göttinger Orientforschungen Syriaca 38 (Wiesbaden: Harrassowitz Verlag), p.149.

Hierotheos, Metropolitan of Nafpaktos 2000 [1997]. Saint Gregory Palamas as a Hagiorite. Levadia: Birth of Theotokos Monastery, pp.339, 342-343.

LOSSKY, V.

1975. In the image and likeness of God. London and Oxford: Mowbrays.

1983. The vision of God. Crestwood, New York: St. Vladimir's Seminary Press.

MeYendorfF, J.

1959. St. Grégoire Palamas et la mystique orthodoxe. Paris: Editions de Seuil.

Palamas, G.

1992. Pros Xenin monahin. In: P. Xrestou (ed.), Syggramata V (Thessaloniki: Oikos Kyromanos), pp.223-224.

1988. The one hundred and fifty chapters (Capita 150). Translated by R.E. Sinkewicz, C. S. B.). Toronto: Pontifical Institute of Mediaeval Studies.

1983. The triads (Hyper tōn hierōs hesychazontōn). New Jersey: Paulist Press.

2009. Tomusuri dogmatice - Viața - Slujba. Scrieri I. Translated by I.I. Ică. Sibiu: Editura Deisis.

2010 [1962, 1988]. Hyper tōn hierōs hesychazontōn. In: B. Bobrinsky, P. Papaevaggelos, J. Meyendorff \& P. Xrestou (eds.) Syggramata I (Thessaloniky: Oikos Kyromanos), pp.425, 463.

Papademetriou, G.

1973. Introduction to Saint Gregory Palamas. New York: Philosophical Library.

$\begin{array}{ll}\text { Keywords } & \text { Sleutelwoorde } \\ \text { Divine light } & \text { Goddelike lig } \\ \text { Transfiguration } & \text { Verheerliking } \\ \text { Gregory Palamas } & \text { Gregory Palamas } \\ \text { Deification } & \text { Vergoddeliking }\end{array}$

